\title{
International diffusion of regulatory governance: EU actorness in public procurement
}

\author{
Stella Ladi $\mathbb{D}$ * \\ School of Business and Management, Queen Mary University of London, London, UK \\ Department of Political Science and History, Panteion University, Athens, Greece \\ Dimitris Tsarouhas \\ Department of International Relations, Bilkent University, Ankara, Turkey
}

\begin{abstract}
This paper attempts to go beyond actor-centered explanations of the European Union's (EU) presence in regulatory politics by examining the role of the EU in the diffusion of regulatory norms and practices. We explore the international diffusion of public procurement policy, to which multiple organizations and especially the EU and the World Trade Organization have made an active contribution. Using the "opportunity-presence-capability" scheme, we argue that the EU is actively co-shaping the global agenda on public procurement, mainly as a result of the "opportunity" and "presence" dimensions of its global actorness and its role in the horizontal diffusion of public procurement regulations between international organizations. For "EU as a global actor" literature to offer valuable explanations, an in-depth analysis of its relationship with other international organizations, such as the World Trade Organization, reveals significant interactions and the co-shaping of policy agendas.
\end{abstract}

Keywords: European Union, global actor, regulatory politics, diffusion, public procurement, World Trade Organization.

\section{Introduction}

Regulatory governance can increasingly be described as a transnational legal order in which a number of international organizations interact for the diffusion of regulatory norms and practices. The World Trade Organization (WTO) shapes regulations in more countries than many other international organizations (IOs) (Shaffer 2015). At the same time, the European Union (EU) has over time enhanced its international presence and seeks to expand its role as a global actor. Although the EU's role as a global actor is disputed, its role in trade and in the internationalization of public procurement regulation demonstrates that it remains central in the global scene. To shed light on the EU's specific influence at global level, a sizable literature has developed in recent years (e.g. Bretherton \& Vogler 2006; Young 2015). EU actorness and the ways in which this is manifested are of particular significance in this regard, yet the literature does not adequately focus on the international environment and the diffusion of norms and practices (see Levi-Faur 2005). Instead, it tends to focus primarily on the EU's policymaking competences and capacities.

In this article we explore the necessary conditions for the EU to act as a global actor. Our starting point is the literature on EU actorness and especially its three dimensions, as identified by Bretherton and Vogler (2006): presence, opportunity, and capability. We argue that although the EU actorness literature offers valuable tools to detect the EU's specific role in global politics, it nevertheless suffers from a key theoretical and ultimately empirical shortcoming. Although presence and opportunity are acknowledged, the literature mainly focuses on capability. Capability is inadequate, on its own, to explain broader global trends, such as the internationalization of public procurement regulation. However, the EU's formation and development as a regulatory actor should be seen in the broader context of international regulatory governance. Opportunity and presence are key because regulatory policies are often diffused horizontally between IOs. They cannot therefore be understood merely as the result of the strategic actions of a single

Correspondence: Stella Ladi, School of Business and Management, Queen Mary University of London, Mile End Road, Bancroft

Building, Room 3.44g, London E1 4NS UK. Email: s.ladi@qmul.ac.uk

Accepted for publication 13 May 2017.

(C) 2017 John Wiley \& Sons Australia, Ltd 
global actor. The EU may act as a global actor but other structural factors, as well as diffusion, play an equally important role. Empirical research on EU actorness should therefore take into account the international diffusion of regulatory norms and practices and, within this context, analyze the EU's role.

More concretely, in this article we look at the Union's engagement in the international diffusion of regulatory norms and practices in the area of public procurement. The empirical question that we explore, in light of the theoretical propositions put forward, is whether the EU manifests actorness in shaping public procurement rules at a global level and if so, through what means and under what circumstances. Special attention is paid to interaction with the WTO because of the latter's increased significance in recent years and the fact that it has become a central international actor in the field through the Government Procurement Agreement (GPA). Our case study selection stems first, from the growing importance of international trade in world politics, and the consolidation of "deep trade" issues (among them procurement policy) as vital to states' and organizations' attempts to promote multiple economic and political objectives through them. Second, changes in public procurement regulation are particularly important for public governance, as they cannot be simply understood as attempts to liberalize one more trade area. Public procurement regulation has a direct impact upon government choices about the delivery of public services.

In what follows, we begin with a theoretical overview of the $\mathrm{EU}$ as a global actor, identifying the diverse strands of this literature and locating our own contribution in it. We also outline the reasons behind our selection of trade policy and specifically public procurement, before adding a note on our methodological approach. The next sections analyze the role of the EU in the internationalization of public procurement regulation by discussing all three dimensions of EU actorness separately: opportunity, presence, and capacity. The conclusion summarizes the main theoretical and empirical argument, before discussing possible avenues of further research.

\section{The European Union as a global actor and regulatory diffusion}

The EU has long been seen as an ascending power in international politics (Galtung 1973; Moravcsik 2002; Reid 2004) and an ongoing discussion on EU actorness has been taking place. This discussion has been limited exactly because of its focus on actorness and its lack of concern for regulatory and policy diffusion. For international law scholars, actorness is limited to the EU's legal personality, while for realist international relations scholars, actorness should be understood in terms of statehood and different versions of power politics. Taking into account behavioralist, structuralist, and constructivist arguments has led to a more rounded understanding of actorness (Bretherton \& Vogler 2006). In this article, we argue that a diffusion perspective should be added in order to obtain a more comprehensive understanding of the EU's role. Bretherton and Vogler (2006) identified three dimensions to actorness that are central to our model:

- Opportunity, which relates to the external environment of ideas and events that can constrain or enable actorness during different times (i.e. what happens in regulatory regimes beyond the borders of the EU, potentially encompassing other organizations as well).

- Presence, which refers to the ability of the EU, in an intended or often unintended manner, to exert influence beyond its borders (e.g. the Single Market and the spur it has provided for regulatory reform in other policy areas for the EU and beyond).

- Capability, which sheds light on the availability of policy instruments and the ability of the EU to utilize these instruments, in response to opportunity and/or in order to capitalize on the benefits of presence.

There is consensus in the literature that all three of these dimensions have allowed the EU, depending on the specific case, to act as a global actor or to at least be perceived as one (e.g. Lucarelli \& Fioramonti 2010). We argue that the EU's strategy to internationalize public procurement relates to all three dimensions, but to understand the reasons behind it more attention should be paid to the first two as they leave space for diffusion and more structural reasons to be taken into account.

Diffusion refers to:

[T] he process by which the adoption of innovation by member(s) of a social system is communicated through certain channels and over time and triggers mechanisms that increase the probability of its adoption by other members who have not yet adopted it. (Levi-Faur 2005, p. 23) 
Diffusion moves beyond structural and actor-centered explanations of policy change and helps us elaborate the opportunity and presence dimensions of EU actorness. It allows for broader explanations of the reasons why a specific regulation or policy (e.g. public procurement) has been internationalized and helps us explore the role of the EU within the constellation of other IOs (in this case the WTO, the United Nations [UN] and the Organisation for Economic Cooperation and Development $[\mathrm{OECD}])$. Structural explanations tend to focus on phenomena such as globalization, while actor-centered explanations stress the capability of actors such as the EU to export their own models. Levi-Faur (2005) argues that we need to pay more attention to the horizontal patterns of change (country to country). Taking this as a starting point, we move a step further and propose that more attention should be paid to the horizontal patterns of change between IOs in order to map the diffusion of regulatory policies and practices. "Methodological transnationalism," whereby the interconnectedness of different hierarchical and network structures of both a public and private nature at the transnational, international, and/or global level is revealed, is necessary to understand the complexity of diffusion (Stone \& Ladi 2015).

The initial conceptualizations of actorness saw Europe as a civilian power which, having renounced the use of military means among its member states, could legitimately encourage other regions and countries to do the same (Duchêne 1972). Moving away from the distinction between civilian and military power, Manners (2002) described the $\mathrm{EU}$ as a normative power whose power originates in the rejection of divisive nationalism. "Normative Europe" is based on core values described in the Treaties and has the potential to act as a model, as a promoter of its values, and as a counterweight to the United States (US) (Bretherton \& Vogler 2006). Understanding the EU as a value-based actor has influenced policymakers but has been criticized by scholars for overlooking other material and interest-based factors in EU power projections (e.g. Hyde-Price 2006; Meunier \& Nicolaidis 2006; Zimmermann 2007). In response, a vast literature on the $\mathrm{EU}$ as global economic actor, as a global regulator, as a trade power, and as a market power has developed (for literature reviews see Damro 2015; Young 2015). We argue that a more general criticism is that the literature on EU actorness places too much emphasis on the EU itself and understates structural factors, such as the international diffusion of norms and practices. In any case, the different understandings and types of EU actorness should not be regarded as opposite to each other but as complementary. The internationalization of EU public procurement regulation, which combines liberalization with environmental and social requirements, is a telling example of the coexistence of normative, market, trade, and regulatory attributes in EU actorness.

As mentioned above, the main shortcoming we identify is that the literature on the EU as an economic global actor has mainly focused on the "capability" dimension of EU actorness and specifically on the capacity of the EU to act as a single actor. The "opportunity" and "presence" dimensions that can lead to policy and regulatory diffusion have been neglected (with exceptions, see Bretherton \& Vogler 2013). The EU has in the recent past often appeared disunited in the face of external challenges, facing severe criticism over its alleged weakness at the international level. Although this weakness is often assumed to derive from the EU's low policy coherence (Jørgensen et al. 2011), recent data suggests a more nuanced relationship between effectiveness and coherence. EU diversity does not necessarily result in low effectiveness at the international level; "depending on the policy areas and the bargaining configuration" under study, high cohesiveness can even result in low effectiveness (Conceição-Heldt \& Meunier 2014, p. 975). Similarly, a large part of the literature discusses the economic clout of the EU in multilateral or bilateral trade negotiations from the starting point of the EU's institutional setup. Focusing on "capability" offers valuable findings on the success and failure of EU external strategies but cannot explain why the agenda shifts to new areas, such as public procurement, or why the EU continues to influence the international agenda despite its apparent lack of capacity. We argue that more attention should be paid to the dimensions of "opportunity" and "presence." Young (2015) claims that in order to understand the EU's engagement in the world, general theories of international political economy should be employed, not least the changing constellation of power in the world system through the rise of emerging market economies and the interconnections between different IOs who often pursue parallel policy agendas. By focusing on EU's "opportunity" and "presence" in new policy areas, this is exactly what we hereby attempt to do.

European Union trade policy is one of the most interesting policies to expand the EU actorness discussion and to combine it with the diffusion literature (see Billiet 2006; Damro 2007; Elsig 2002, 2007). Despite the rise of new powers such as Brazil, China, and India, the EU remains the world's largest market and trader. Young and Peterson (2014) argue that we need to analyze EU trade policy in its different subsystems in order to gain a complete picture (e.g. multilateral trade liberalization vs. anti-dumping policies). Interestingly, when focusing on the subsystem of low average tariffs on manufactured goods, the EU can be portrayed as a liberal force, yet when considering the 
trade restricting effects of $\mathrm{EU}$ internal regulations, the $\mathrm{EU}$ is best described as a protectionist system. Public procurement combines both.

\subsection{Why public procurement policy?}

Public procurement is particularly important, not least because it is relatively understudied from a public policy/ governance perspective. The global procurement market is valued at US $\$ 1.7$ trillion, while government procurement accounts for between 15 and 20 percent of global gross domestic product (GDP). Moreover, public procurement is a lucrative market for the EU, as well as an important contributor to EU GDP. It represents roughly 14 percent of EU-27 GDP as of 2016 (European Commission [EC] 2005). It covers the public organization purchase of goods and services, such as pharmaceuticals, medical equipment, railway, and urban transport equipment. All national public procurement above specific thresholds is covered by EU Directives (Young \& Peterson 2006). As an EU trade policy, this subsystem is particularly interesting as it simultaneously portrays liberal and protectionist characteristics. This last fact is connected with the increasing prominence of public procurement as a core pillar of "deep trade" issues that have emerged over the last two decades in the international economic scene. The contribution of public procurement to trade policy is now increasingly recognized as multi-faceted and not merely restricted to facilitating trade flows. Rather it is directly linked to broader governance issues, including transparency, value for money, and good governance. The dynamics of the Single Market and the application of the non-discrimination principle beyond the EU offer lucrative opportunities to European multinational corporations (MNCs) while strengthening the EU's regulatory role both domestically (with stringent enforcement of existing rules) and globally (via the diffusion of EU policy preferences).

The literature on EU public procurement policy, whether in its esoteric, EU dimension and the relevant policies and legislation, or the Union's engagement globally through the WTO, attempts to answer the same question as the rest of the literature (Blauberger \& Krämer 2013; Bovis 2013). The principal focus is the ability of the Commission to engage in regulatory transfer to the WTO in procurement, and the obstacles posed in the process. However, the "opportunity" and "presence" dimensions of this transfer are again omitted.

\subsection{A note on methodology}

We make use of a qualitative methodological framework, relying on primary sources derived from the EU, WTO, UN and OECD databases, including policy reports and data on public procurement-related policy initiatives, such as the green/sustainable public procurement (GPP/SPP) advisory group launched by the European Commission (EC). Minutes from the network's meetings and bilateral EU-WTO meetings have been incorporated in the analysis. Further, we conducted 13 face-to-face, semi-structured interviews with senior policy officers of the EU and the WTO in Brussels, Geneva, and Istanbul to verify material already obtained and confirm our hypothesis on the role that diffusion plays regarding public procurement regulation.

\section{EU actorness in public procurement: Opportunity, presence, and capability}

European Union actorness in public procurement manifests itself in line with the core dimensions of actorness we identified above, namely opportunity, presence, and capability. We investigate each in turn and identify the mechanisms that lead to their realization. This allows us to contextualize EU actorness by incorporating diffusion as well as agency-derived variables into our analysis. Public procurement is a particularly ripe field to undertake such an exercise, as the $\mathrm{EU}$ is but one of the players that lead to the formulation and revision of procurement rules at global level. At the same time, its role as agent is significant because of the long-lasting experience it has acquired in dealing with deep trade issues for a number of decades.

\subsection{Opportunity}

European Union actorness in public procurement, just as in other policy fields, takes place in context. It is shaped by the diffusion of ideas and actions between IOs in relation to the role of trade in international political economy (horizontal diffusion). In that sense, empirical data reveals the centrality of the WTO in seeking to coordinate global procurement rules. Its interaction with the EU is of central importance. Ideas (in the form of the "Singapore issues" discussed), as well as events (the signing and updating of the GPA), highlight the centrality of opportunity in better understanding 
EU actorness. We analyze both further. By examining the interaction of the EU with other states and IOs in formulating, reforming, and expanding the regulatory terrain on public procurement, we can better understand the dynamics behind EU actorness. We begin with an investigation of the role played by IOs in pushing for a new regulatory regime and examine their role in turn.

3.1.1. Horizontal diffusion and international organizations. The OECD has played a crucial role in rule-setting on public procurement from an early period. Starting from the 1960s, the OECD sought to complement nondiscriminatory access to procurement markets with the introduction of rules to achieve procedural conformity between its members, not least the US and the (then) European Economic Communities (Trepte 2005, p. 1127). Rules agreed at the OECD level, with the US playing a key role, have had a direct impact on allowing the EU to develop its own legislative framework on procurement, as will be discussed further. Suffice to say here that the close cooperation between the EU and the OECD on procurement acquired an institutional dimension through the setting up of OECD Support for Improvement in Governance and Management (SIGMA). The latter is an OECD body principally financed by the EU that delivers advice, offers reform recommendations, and seeks to enhance cooperation between the OECD, the EU, and external actors, including in public procurement. OECD work on procurement, containing initiatives in partnership with other IOs, is ongoing.

The search for regulatory templates in the field of procurement acquired another dimension in 1994, when the UN, through the United Nations Commission on International Trade Law (UNCITRAL) issued its Model Law on Procurement of Goods, Construction and Services, which was subsequently amended in 2011. EU, OECD, WTO and UNCITRAL updates and the modernization of their rules thus followed closely, although the content of their respective Codes, Norms (OECD), Directives (EU), and Agreements (WTO) differ in content to varying degrees. Both the 1994 and 2011 versions of the UNCITRAL Model law provide a non-binding template for states to follow when procuring for their internal market. While heavily influenced by the GPA, as well as the EU Directives on procurement and remedies, the Model Law seeks to promote international competition in procurement through harmonization instead of imposing a mandatory text (European Bank for Reconstruction and Development [EBRD] 2016). As a consequence, UNCITRAL tends to be more flexible than the latest EU Procurement Directives in allowing for national preferences in procurement as long as this is performed in a transparent manner (Organisation for Economic Cooperation and Development [OECD] 2000). On the other hand, the UNCITRAL Model Law includes guidance for states on issues not dealt with in the EU Directives (i.e. on low-value purchases), to entice states to avoid corruption and obtain value for money (Arrowsmith 2009, p. 259).

In the context of EU actorness, the role of the WTO deserves special attention: both ideas and events (the Singapore issues and the GPA, respectively) are key examples of opportunity, within which the EU seeks to assert a global role. It is to these core aspects of opportunity we turn next.

\subsubsection{The World Trade Organization, the Government Procurement Agreement, and the global role of the EU in}

procurement. For all the crucial work undertaken in procurement by the OECD, the UN, or the US, the WTO (starting from its predecessor, the General Agreement on Tariffs and Trade [GATT]) has been at the forefront of global regulatory standards on public procurement, shaping the framework within which its members have revised or updated their procurement practices. Public procurement was a policy area excluded from the GATT's most favored nation and national treatment principles in 1948. This is because of its controversial nature for vote-seeking politicians: "using taxpayers' money to give jobs and contracts to foreign workers and companies is not the best way to win votes" (Woolcock 2012, p. 5). Nonetheless, first attempts were made during the Tokyo Round of Multilateral Trade Negotiations in the 1970s, and led to the 1979 Tokyo Round Code on Government Procurement (Reich 2009). The Code owed much to the work undertaken by the OECD in this field, whose 1976 report led the groundwork for the 1979 agreement. Article IX: 6 of the Code foresaw the establishment of the Committee on Government Procurement (CGP) (Trepte 2005, p. 1129). The role of the US in the process was also critical, not least in co-shaping the Code.

By the early 1990s, GATT became the WTO and procurement policy acquired a substantial new dimension. The signing of the GPA and the formation of the WTO had very important consequences for trade policy, changing the opportunity environment within which the EU operated. Until then, trade for powerful blocs such as the EU focused on assurances of mutual market access. This became increasingly unsustainable, as major trade constituencies in the 
advanced industrialized world started pressuring political authorities to move beyond market access and insert policy regulation on the trade agenda (De Bièvre 2006). This is a consequence of the rise in new trade politics, which does not limit trade policy to traditional issues around tariff reductions and market access (Young \& Peterson 2006). The new approach is cognizant of the fact that in an era when divergent environmental, labor, and social standards are a key feature in investment decisions, exporting domestic regulation practices is a long-term strategy to guarantee increased aggregate trade volumes as well as sustainable market access.

The most important regulatory instrument on procurement for advanced states and organizations is the GPA, first signed in 1994 and modernized 20 years later. Also known as the Marrakesh Agreement on Government Procurement, the GPA aimed to liberalize procurement markets worldwide. Crucially, the GPA included the procurement of both goods and services. Content-wise, the GPA promoted competition on government procurement as much as possible. It relied on core principles, such as transparency, good governance, and non-discrimination (Anderson et al. 2012, 2013). These principles were designed to enhance competition for contracts, stimulate an improved "value for money" setup for public contracts, and avert a return to protectionism. Nevertheless, the liberal face of the EU can be demonstrated by the fact that companies originating in countries that are parties to the GPA are treated as EU companies (Young \& Peterson 2014). The GPA entered into force in 1996, and negotiations began swiftly thereafter for its revision. The GPA is a plurilateral agreement and consists of 19 parties and 47 WTO members, with many other states and four IOs (the International Monetary Fund, OECD, United Nations Conference on Trade and Development, and the International Trade Center) maintaining observer status. Following a protracted period of renegotiations and ratification by acceding parties, the revised GPA entered into force in April 2014.

Opportunity manifests itself through the GPA but is not merely an external event calling for EU reaction: it is actively co-shaped by the EU given its prominent role in global regulatory politics. The 1994 GPA was itself based on key EU concepts surrounding the appropriate design and execution of procurement contracts as the EU has one of the most developed public procurement regulatory frameworks in the world. ${ }^{1}$ This is far from coincidental: at a structural level, the EU has a clear advantage over the majority of other WTO members resulting from the bloc's long experience in handling trade negotiations and pursuing a strategy of multilateralism based on the non-discrimination principle. Yet the relationship is clearly not one way: the adoption of the GPA in 1994 provided the impetus for the EU's new internal market procurement legislation borrowing from concepts developed at WTO level. ${ }^{2}$ To illustrate, the revision of EU internal procurement legislation launched following the 1996 Commission Green Paper took place in light of the then new GPA and the rules this included (EC 1996).

When it comes to the revised GPA of 2014, it bears the imprint of the EU in important respects: the right to appeal clauses, the judicial review mechanism, and e-procurement were all part of previous EU legislation. ${ }^{3}$ The EU has thus had a substantial impact in setting the framework on which the revised GPA would be based; in fact, the new GPA is "very much in harmony" with the EU Directives on public procurement. ${ }^{4}$ In some cases, the EU utilized the GPA agreement verbatim when seeking to reach new agreements, with third parties, such as the (not yet concluded) Association Agreement with Azerbaijan. ${ }^{5}$

The role of the EU in the WTO is thus of crucial significance. The EU (along with the US) has been one of the foremost proponents of the WTO's establishment as part of its commitment to multilateral trade and a new trade agenda in the early 1990s (Blank \& Marceau 1996). Further, the WTO has adopted an "increasingly legalistic approach" (Billiet 2006) to dispute settlement through the Dispute Settlement Mechanism (DSM). In relation to public procurement, the WTO "applies key common rules and ensures the predictability necessary for EU traders to rely on those rules vis a vis GPA signatory states" (Casavola 2011, p. 317). This is also particularly important for the EU on another level: the EU's supreme judicial body, the Court of Justice (CJEU) has issued a number of decisions facilitating public procurement regulation according to three core EU principles, namely non-discrimination, transparency, and competition (Bovis 2013). Finally, the decisionmaking structure of the WTO makes it difficult for less powerful states to influence its decisions. WTO Committees and Working Groups require high administrative expertise, ample resources, and functional cooperation (Casavola 2011). These are necessary to create the sort of coalitions of states that will then convince other members to go along with a specific proposal. The EU's modus operandi is based on such ability, having to reconcile divergent state interests on a daily basis. Its adequate resources and expertise on trade matters add to its ability to influence the WTO decisionmaking process.

The above is true in the specific case of the CGP. Despite its longevity, the CGP remains a negotiating forum among its 45 members (28 of which are EU member states). The lack of transparency in CGP proceedings offers a disincentive 
to developing countries to join, and even the cost of attending the CGP periodic meetings (four such meetings are held every year) can be considered prohibitive for non-Western states (Casavola 2011). If the GPA has been a key event in terms of opportunity for the EU, ideas are equally significant. The new context shaped by the GPA has influenced the EU's ideational approach to procurement and led to the tabling of the "Singapore issues," to which we now turn.

Following the signing of the first GPA, EU public procurement bidders started voicing their demands for improved access to public procurement markets outside Europe. Echoing those demands, the EU (along with the US) has been instrumental in tabling the so-called "Singapore Issues" at the first WTO ministerial conference in 1996. Those issues included competition, investment, trade facilitation, and transparency in public procurement rules, with the then responsible Commissioner Leon Brittan arguing explicitly for the need to include competition policy, foreign direct investment, and environmental and labor standards in the so-called "Millennium Round" (Deutsch 2001). By the same token, new rules on public procurement enhancing transparency and limiting corruption were seen by EU representatives as key to enhance efficiency, facilitate trade, and assist in the economic development of the least developed countries (De Bièvre 2006). ${ }^{6}$ Importantly, the EU has consistently sought to put this issue at the forefront of multilateral trade negotiations via the WTO, instead of seeking to utilize other IOs. ${ }^{7}$

The Directorate-General for Trade took the lead during the Doha Round, calling for enhanced transparency in procurement policy to level the playing field of international competition (Damro 2007). ${ }^{8}$ The EU regulatory strategy met with limited success, however. Developing countries were particularly vocal in their refusal to advance the Singapore issues. In 2004 and despite last-minute attempts by then Trade Commissioner Lamy to shelve some of the Singapore issues in order to reach an agreement, the WTO decided to exclude negotiations on transparency in public procurement (as well as investment and competition policy) (De Bièvre 2006). This came despite the fact that the Doha Ministerial had agreed to set up a working group on Transparency in Government Procurement. That group was multilateral and included all WTO members. It carried out a study of 12 issues in total, with the prospect of incorporating some of those in a future agreement. Technical assistance, capacity building, and the potential elements of an agreement on transparency in procurement formed the core of the study (World Trade Organization [WTO] 2016), yet the 2004 decision by the General Council excluded the Singapore issues from the Doha Round.

\subsection{Presence}

Explaining the ways in which opportunity manifests itself, not least through the role played by IOs, is the first step in comprehending EU actorness. Yet if opportunity is manifested through the multiple contact points between IOs diffusing their practices, rules, and norms on procurement, how does the EU establish its presence in procurement rules? In this section, we argue that the Single Market and the development of a dense legislative framework on procurement have offered the EU the ability to actively shape rules that have been incorporated in the GPA.

3.2.1. The Single Market. The Single Market is central in understanding the EU's regulatory influence as a result of its "presence," which in turn enhances its "capability" as a global actor. Young and Peterson (2014) argue that this is happening for two reasons. First, because the adoption of common rules means that the EU has something very concrete to export and defend, and second, because some EU regulations, such as data privacy and risk regulation, are the strictest in the world and affect foreign firms trying to enter the EU market. The result is that these firms support regulatory cooperation with the EU to improve their access, and block the ability of EU firms to monopolize the European market. ${ }^{9}$

European Union public procurement regulations belong to this same category and are pertinent for further internationalization. The Single Market offers the EU a distinct advantage in formulating non-discrimination trade policies and opening up procurement markets to firms from throughout the EU. It is far from coincidental that the 2011 Single Market Act recognized the strategic importance of public procurement in furthering European integration, which in this instance is directly associated with the operation of the Single Market (Bovis 2013).

The Commission's 2005 Communication Global Europe: Competing in the World verifies the usefulness of the Single Market in terms of both the promotion of internal competition among EU firms and as a tool to shape global rules and norms governing trade. "The single market...promote[s] predictability and transparency and allow[s] business to exploit market size and economies of scale...It has fostered the development of high-quality rules and standards which shape global norms" (EC 2005, p. 3, emphasis added). The same Communication attributes a 
particularly important role to procurement, perceiving it as a "new trade area of economic importance to us" (EC 2005, p.6). Procurement is also an:

....area of significant untapped potential for EU exporters. EU companies are world leaders in areas such as transport equipment, public works and utilities. But they face discriminatory practices in almost all of our trading partners... this is probably the biggest trade sector remaining sheltered from multilateral disciplines. (EC 2005, p.7, emphasis added)

Moreover, public procurement policy at EU level has allowed the EU to develop the internal market further. Arrowsmith and Kunzlik (2009) identify three means by which this process is facilitated: anti-discrimination policies, ensuring transparency, and removing non-discriminatory restrictions on access to the internal market. In addition CJEU decisions, such as the cases of Concordia and EVN Wiestrom, facilitate the work of local authorities when procuring to do so by taking into account social and environmental objectives next to cost considerations (Semple 2012). ${ }^{10}$ Moreover, the Single Market program facilitated the creation of standard contract award procedures, combined with growing pan-European competition as a result of mergers and investment across the EU, which enhanced firms' confidence in their ability to win contracts in the EU. By extending coverage, the Single Market "facilitated the extension of the GPA" (Woolcock 2012, p. 10) and placed the EU at the forefront of procurement regulation. External actorness via presence went through domestic regulatory reform and the initiation of an ambitious, comprehensive reform project.

Yet the balance between internal regulatory reform and external actorness is always thin. The existence of the Single Market is a potential challenge to EU competitiveness, to the extent that its stringent rules on state aid (part of which is related to public procurement policy) could be an obstacle to MNC's global market expansion (Blauberger \& Krämer 2013). The EC's State Aid Action Plan published in 2005 drew a lot of reaction from important associations, such as the French Business Confederation Mouvement des enterprises de France, for its lack of "global ambition." 11 The conscious strategy by the EU to export its procurement rules has therefore also been a result of internal (EU) lobbying pressure to harmonize global rules so as not to disadvantage European MNCs (Blauberger \& Krämer 2013). "Exporting" EU rules allows firms to save on transaction costs related to different rules being applicable in different jurisdictions; it also permits firms knowledgeable of EU rules to retain important administrative advantages in bidding beyond EU territory and when entering foreign markets, given the high degree of similarity in approach between EU and WTO rules on procurement. ${ }^{12}$

3.2.2. EU public procurement Directives. European Union public procurement legislation has its origins in the Rome Treaty and the prohibition of barriers to trade, as well as the establishment of freedom of movement and service provision. Successive Directives related to public works and supplies (as well as concessions) have been passed since, with every new piece of legislation aiming at a greater degree of legal harmonization and, since the 1990s, the simplification of legislative procedures.

European Union know-how on public procurement stretches back to the 1960s, when the first relevant Directives were passed. The first came in 1966 (66/683) and 1970 (70/32), according to which no discrimination between national and foreign products would be allowed in public procurement and public supply contracts, respectively (Bovis 2007). These were enacted following extensive cross-fertilization with the OECD. It is revealing that both 66/683 and 70/32 "essentially took the same approach as that discussed in the OECD" (Bovis 2007, p. 1129). In 1977, Directive 77/62 added more details in Community legislation by requesting the specification of "objective criteria" in tendering and award procedures, as well as the prohibition of discrimination over technical specifications. Nevertheless, procurement remained subject to non-transparent practices, and the Single Market program identified the diverse rules surrounding member states' procurement policies as a significant non-technical barrier to trade. ${ }^{13}$

The Commission's cooperation with private firms goes back to the late 1990s, and industrial firms were particularly active in the revision of the Directives. ${ }^{14}$ Directive 89/440 amended previous public works Directives and widened its scope of application to cover concessions and state-subsidized works. This Directive is most closely linked to the GPA and reveals that the aims were very similar to equivalent work undertaken at the WTO: increase value for money, enhance transparency in the awarding of public contracts, and potentially contribute to socioeconomic advancement. Moreover, the Directive was influenced by the political context of the time and in particular the Treaty-specified 
objectives of social and environmental sustainability (Beuter 2005). Through Directive 89/665, contracting authorities were obliged to certify that their procedures adhered to procurement law and that their decisions would be subject to effective judicial review by national authorities (Bovis 2007). Finally, Directive 93/37 sought to make the legal framework less heterogeneous and included detailed references to due process regarding the award of concessions. Given the need to update and harmonize procurement legislation, and as a consequence of OECD, WTO, and UNCITRAL work in the field, the EU conducted a significant revision in the 2000s. ${ }^{15}$ First in 2004, the EU adopted a Directive on procurement in water, transport, energy, and postal services (the Utilities Directive 2004/17/EC); another on public works, supply, and service contracts (2004/18/EC); and a third on concessions (2014/23/EU). Since 2009 a different Directive governs defense and security procurement (2009/81/EC). In December 2011, the EC published its proposals for legislation to replace the existent Directives on procurement. Extensive amendments introduced by the European Parliament and Council led to a compromise text in 2013. The process was completed in 2014, after the Council adopted the new procurement Directives following European Parliament approval.

Directive 2014/25/EU ("the Utilities Directive") replaced 2004/17EC, while Directive 2014/24/EU ("the Public Services Directive") replaced 2004/18/EC. The new Directives in Article 1 in the Utilities and 1(4) in the Public Services Directive explicitly state that member states are at liberty to decide how to deliver public tasks and services of general economic interest (OECD 2014, p. 4). Compared to the 2004 Directives, the new legislation places more emphasis on electronic procurement and broadens the possibility of taking social and environmental considerations into account when specifying technical considerations in line with the development of CJEU case law. Finally, the new Directives seek to further encourage small and medium enterprise (SME) participation in procurement and allow for the possibility of bearing in mind lifecycle cost criteria in determining winning bids in tendering, aside from the lowest priced tender (Articles 67 and 82, respectively). However, the exact wording in the two Directives allows for different interpretations, given that the text resulted from a compromise reached between the Parliament and Council (OECD 2014, p. 22).

Be that as it may, the Directives reveal a strong EU presence, accompanied by the acquisition of a certain reputation in the field and expectations of action. The protectionist character of the EU procurement Directives is reflected in discrimination against foreign firms. Any bid in which more than half of the value of its products originates outside the EU can be rejected (Young \& Peterson 2014; Maughan 2016). According to the Commission, the motivating factors behind the revision were "economic, social and political developments and current budgetary constraints" (EC 2014a), reflecting the EU's desire to apply the reciprocity principle to those states and markets unwilling to follow its own (at least rhetorical) desire to fully open up their markets to EU firms. As the EC put it in its 2015 Communication Trade for All: "while the EU has progressively integrated and opened its markets, EU companies still encounter discrimination and restrictions abroad" (EC 2012, p. 10). The new Directives have now been adopted and member states have had a grace period of two years to implement them.

\subsection{Capability}

European Union actorness manifests itself in a structural context of policy diffusion and interaction (opportunity), through the EU's strong presence in global regulatory reform by use of the Single Market (presence), as well as its more explicitly agency-related ability through specific advantages in procurement (sustainable procurement practices). Structural and agency-related variables coexist and together make up EU actorness. According to Bretherton and Vogler (2006), capability links to policy formulation and the EU's ability to act coherently is crucial in this regard. The distinction between vertical and horizontal coherence is important here: while the former denotes the degree of consistence of EU external policies and their linkage to one another, the latter is about the possible tensions, or synergies, between different policy areas. Furthermore, capability manifests itself through the formulation of policies to incentivize what it deems appropriate behavior by others through political, economic, or military means (Bretherton \& Vogler 2013, p. 385). We outline the concrete manifestations of EU capability in procurement by use of two coherence levels, vertical and horizontal. We also demonstrate its use of specific policies at bilateral (free trade agreements) and global (WTO) level to demonstrate its role as a global actor.

3.3.1. Vertical coherence. In terms of vertical coherence, trade policy is a rather uncontested area in that the EU has developed a high degree of coherence. In public procurement and at the level of the WTO, all EU member states are 
parties to the GPA, and the EU counts as one party. In practice, the EC negotiates as a representative of the member states who, although present in the room, avoid intervening. It is the EC that represents the Union as a whole and member states do not take the floor, despite the fact that they have the formal right to do so under WTO rules. ${ }^{16}$ The issue of EC-member state competences and membership in the WTO has a long history. In fact, disagreements between the member states and the EC as to the exact competences of each meant that the EC brought the issue to the CJEU in 1994. The Court's verdict was mixed, in that the EU obtained exclusive competence on cross-border services and trade in goods, whereas this was not the case for other modes of trade in services and trade-related intellectual property rights (Hilf 1995). The WTO charter was thus signed as a "mixed competences" agreement, resulting in the fact that both the EU and member states partake in the organisation. In practice, the EC's supremacy over member states is manifested in the EC's seating order, whereby EC representatives sit in the front row and member states behind them. An important proviso here is that the EC interacts constantly with member states, not least informally, and member states are kept up to date regarding the EC's negotiating tactics and intentions. ${ }^{17}$

Nonetheless, the internal division of labor within the EC is not completely trouble-free: ${ }^{18}$ the Directorate Generals for Market and Trade have separate mandates and "different working cultures." ${ }^{19}$ While DG Markt is responsible for GPA negotiations, it is DG Trade that looks at international trade negotiations; as the two issues intersect, coordination issues can arise (Hilf 1995). DG Markt has actively been using consultation processes for the discussion of the modernization of the procurement directives but not for the GPA revision, as this was regarded an international issue where formal consultation was not considered necessary. DG Trade, on the other hand, uses such consultations extensively to involve civil society groups, non-governmental organizations, and trade unions as well as private interest groups (Crespy 2014, p. 105). Yet this does not conceal the fact that DG Trade often echoes the views of business more than other groups, and that interest representation can potentially be unequal (Kohler-Koch \& Finke 2007).

\subsubsection{Horizontal coherence. Horizontal coherence depends on the extent to which there are tensions or synergies} between policy sectors. Procurement, being a deep trade issue, means that the EU has had to invest quite a bit in developing synergies among DGs and draw on outside expertise to raise its capacity and meet its goals. The EC has set up two groups on procurement policy, involving firms, employers, employee representatives, and specialists. The first group, set up in 2011, deals with public procurement in general and is tasked with offering expert advice to the EC "with a view to assisting it in shaping the public procurement policy of the Union" (EC 2011). Selected experts represent a number of member states (14 in total) and retain expertise on, inter alia, the environmental and social aspects of procurement policy.

The second group was launched in 2005 and deals with GPP. A permanent, albeit informal, advisory group, it is tasked with the promotion of GPP and to assist the EC in its efforts regarding legislative proposals (EC 2014b). Not least through the Group's contributions, the EC has developed common GPP criteria covering 19 product and service groups, which address the environmental impact of products and services across the entire lifecycle (EC 2009; Semple 2012). By use of a soft approach promoting the contributions and methodological tools followed by pioneering member states (the "Green 7" member states), the EC has published numerous studies and reports on sustainable public procurement (EC 2007). Pioneering member states are tasked with the development of common GPP criteria; Sweden, for instance, would develop EU-wide criteria on medical electronic equipment (EC 2011). The EU directly links such developments to its presence in global trade. A 2010 policy statement on "Trade, Growth and World Affairs" called for fairness in public procurement, echoing the EU's grievances on unfair treatment by EU firms abroad. Importantly, it also named sectors where EU firms were competitive and should push for public contracts outside the EU market, including in green technologies (Woolcock 2012, p. 10).

Despite varying success across the EU in implementing high GPP/SPP standards, there is little doubt that there is by now "widespread incorporation of both environmental and social considerations in regulated procurement procedures..." (Semple 2012, p. 4). The contribution of local stakeholders, especially local authorities, has been very important, and the GPP Advisory Group includes NGOs (such as the European Environmental Bureau) as well as the International Council for Local Environmental Initiatives, a network of over 1,000 local and metropolitan governments that have assisted the formation of the EU's toolkit on GPP. ${ }^{20}$

Crucially, the EC admits the economic case for GPP criteria to be harmonized across the EU: such a policy would be necessary to "avoid a distortion of the single market and a reduction of EU-wide competition" (EC 2014c). Further, 
such criteria are of particular salience to "companies operating in more than one member state, as well as to SMEs" (EC 2014c). The pioneering role of the EU in SPP practices has enhanced the EU's "capability" dimension and the advantage the $\mathrm{EU}$ possesses vis a vis other trading blocs.

3.3.3. Policy formulation and policy instruments. By pushing procurement policy onto the WTO agenda, the EU wishes to make good use of further market opportunities and further enhance its expertise to raise EU firms' competitiveness. The Work Programme on Sustainable Public Procurement was launched by the WTO in 2012 and aims at specifying the objectives of such procurement and the ways in which sustainable procurement practices can be made compatible with the "value for money" principle as well as the participating states' international trade obligations (WTO 2012). The EU experience on seeking to monitor SPP outcomes and develop lifecycle cost techniques provides an immediate point of departure for the WTO Committee's work in this area (Semple 2012). ${ }^{21}$ In fact, the renegotiated version of the GPA entails aspects conducive to the development of such outcomes. Article $\mathrm{X}$ (6) allows for technical specifications that "promote the conservation of the natural resources or protect the environment," while Article X (9) includes environmental characteristics in the indicative list of tender evaluation criteria (Semple 2012). Finally, launching such a work program under the auspices of the WTO is essential for the $\mathrm{EU}$ in its attempts to achieve its multiple objectives in procurement, namely: (i) avoiding protectionism; (ii) creating a level, non-discriminatory playing field at global level; and (iii) spreading its policy principles on sustainability, including lifecycle cost techniques and "green" procurement. Although the EU was not the sole actor pushing for the establishment of those Work programmes, it had long advocated and expects its own interest to be played out in this policy field. ${ }^{22}$ This is an example of the EU's issue linkage strategy (De Bièvre 2006), through which the EU seeks to reconcile diverse constituencies (exporters as well as domestic producers) and demands (growth and competitiveness in parallel with environmental sustainability). The Works Programmes are ongoing but a senior policy expert involved in the process argues that, given the nature of WTO negotiations and the EU attitude to the Programmes as of now, it is "highly likely" that a sort of "best practice" approach regarding the Programmes will be adopted, and parties will be encouraged to follow best examples of how these types of procurement are conducted across the GPA membership. ${ }^{23}$ In international regulatory cooperation language, this is called "approximation" and bears a striking resemblance to the EU's Open Method of Coordination approach.

In addition to the Work Programme, the modernization of public procurement directives provides the EU with a state of the art regulatory template that can be further diffused. The EU can inspire or indirectly coerce others, particularly in its periphery, to imitate its approach and use EU arrangements as a model. Other policy tools, such as enlargement, have also been put to use in that regard. To illustrate, Central and East European states were originally following the UNCITRAL Model Law on Procurement, but had to align with EU regulatory practices and legislative decisions as soon as their EU candidacy became clear. Others may wish to approximate laws and regulations to EU standards as they "shop around" in search of best practices (Börzel \& Risse 2012, Schimmelfennig 2010).

Crucially, the EU does not hesitate to make a direct link between its economic clout and the explicit policies it wants other states to adopt. This is a tactic used in regional trade agreements and in such instances where the EU seeks to obtain particular concessions. The insertion of a democracy clause in the Preferential Trade Agreement with Mexico is a case in point (Conceição-Heldt 2014). To a certain extent, this has also been EU practice in recent years in the WTO context, as the EU has challenged "protectionist" policies in certain policy areas by the US, as well as countries such as Australia, India, Japan, and Korea (Shaffer 2006). Negotiated trade arrangements with other regional blocs are another example of the EU's regulatory dominance (Maur 2005).

\section{Conclusions}

In this article, "EU as a global actor" literature is enriched by taking into account the observations made in the analysis of international policy diffusion (e.g. Levi-Faur 2005). It is argued that Bretherton and Vogler's (2006) threedimensional analysis of EU's global actorness - presence, opportunity, and capability - is a good starting point. Nevertheless, although in theory the three dimensions have been described as equally important, the empirical analysis has mainly focused on capability. We demonstrate that the EU's advantage stems from the "opportunity" and "presence" dimensions of its global actorness and its role in the horizontal diffusion of public procurement regulations 
between IOs. "Capability" stems from the EU's ability to capitalize "opportunity" and "presence," and is therefore a secondary dimension. For "EU as a global actor" literature to offer valuable explanations, in-depth analysis of its relationship with other IOs, such as the WTO, reveals significant interactions and the co-shaping of policy agendas. Applying a qualitative research design based on thorough documentary analysis and in-depth elite interviewing allowed us to demonstrate the importance of diffusion mechanisms within "opportunity" and its interlinkages with "presence" and "capability."

Public procurement has proven to be a ripe policy field for analyzing the EU's global actorness. Rule-setting in public procurement has been a result of the international diffusion of norms and regulations between a number of IOs, such as the OECD, UNCITRAL, the EU, and the WTO. Within this international "opportunity" structure, the EU has a played a pivotal role in horizontal diffusion between IOs. Our findings go a step further and show that the relationship between the EU and the WTO in the field of public procurement is particularly revealing. Their relationship can be best described as cyclical, meaning that the EU relationship with IOs is not necessarily a one-way effort by the EU to influence the latter's agenda. It can also be cyclical, in that similar actors negotiate in two different fora, exchange information and know-how, and thus shape the international regulatory governance and economic agenda.

This is where the dimension of "presence" becomes important. The EU has developed a strong regulatory capacity in trade issues, including public procurement, through years of technical preparations to enhance competition among its member states and firms. The existence of the Single Market has contributed to the EU's enhancement of procurement rules. The gradual Europeanization of procurement systems at the EU level began in the 1970s and has gathered pace in recent years through the modernization of EU procurement directives. Through that process, the EU has acquired substantial administrative and legal expertise on procurement that allows her to play a global role.

Last but not least, this article outlined the concrete manifestations of EU "capability" in procurement by the use of two coherence levels, vertical and horizontal capability. In terms of vertical coherence, trade policy is a rather uncontested area in that the EU has developed a high degree of coherence. For example, all EU member states are parties to the GPA, and the EU counts as one party. As far as horizontal coherence (coherence between policy sectors) is concerned, the EU had to invest quite a bit in developing synergies among DGs and set up groups with external stakeholders in order to enhance the environmental and social aspects of its procurement policy. A number of policy instruments have been used by the EU to push its agenda to the WTO and internationally, such as the Work Programme on Sustainable Public Procurement launched by the WTO in 2012, or the insertion of a democracy clause by the EU in its Preferential Trade Agreement with Mexico.

To conclude, "opportunity," "presence," and "capability" are three interrelated dimensions of EU actorness. In this article, we have shown that "opportunity" and "presence" should be the starting point of any empirical research on EU actorness, as they provide the structural and diffusion background that allows the EU to capitalize on its resources and demonstrate actorness. Horizontal diffusion of norms and regulations between IOs is the prerequisite of any actorness. Finally, although EU global actorness is hereby adequately demonstrated, the cyclical relationship between the EU and WTO in public procurement underlines the evolving nature of the EU's external economic role and encourages us to further investigate the processes and mechanisms of regulatory capitalism at a time of global economic restructuring.

\section{Acknowledgments}

Part of this research was funded through the Newton Mobility Award Scheme 2014, Award Reference No NG140035. We would also like to thank the participants of the workshop "Global Governance Transformed: Explaining the Nexus between the EU and International Organizations," which took place at Queen Mary University of London (September $24-25,2015)$ as part of this award. Finally, we would like to thank the journal's editor, the three anonymous referees, and Paul Copeland, Tony Payne, and Tore Fougner for their constructive advice on earlier drafts of this article.

\section{Notes}

1 Interview 3.

2 Interviews 1, 13.

3 Interviews 4, 5, 13.

4 Interview 6. 
5 Interview 6.

6 Interviews 3, 4.

7 Interviews 12, 13.

8 Interviews 5, 8.

9 Interview 8.

10 Interviews 2, 10.

11 Interview 7.

12 Interview 6.

13 Interview 4.

14 Interview 4.

15 Interviews 3, 4.

16 Interviews 12, 13.

17 Interviews 3, 12.

18 Interviews 1, 3.

19 Interview 4.

20 Interview 2.

21 Interview 13.

22 Interview 10.

23 Interview 12.

\section{References}

Anderson RD, Schooner SL, Swan CD (2012) The WTO's Revised Government Procurement Agreement. The Government Contractor 54 (1), 1-6.

Anderson RD, Müller AC, Osei-Lah K, De Leon JP, Pelletier P (2013) Government Procurement Provisions in Regional Trade Agreements. In: Arrowsmith S, Anderson RD (eds) The WTO Regime on Government Procurement: Challenge and Reform, pp. 561-656. CUP, Cambridge, UK.

Arrowsmith S (2009) EC Regime on Public Procurement. In: Thai KV (ed) International Handbook of Public Procurement, pp. 251-289. CRC Press, New York.

Arrowsmith S, Kunzlik P (eds) (2009) Social and Environmental Policies in EC Procurement Law: New Directives and New Directions. CUP, Cambridge, UK.

Beuter R (2005) European Public Procurement Reform: Main Innovations in the Public Sector Directive - A Preliminary Assessment. EIPASCOPE 3, 5-11.

Billiet S (2006) From GATT to the WTO: The Internal Struggle for External Competences in the EU. Journal of Common Market Studies 44, 899-919.

Blank A, Marceau G (1996) The History of the Government Procurement Negotiations since 1945. Public Procurement Law Review 5, 77-147.

Blauberger M, Krämer RU (2013) European Competition vs. Global Competiveness: Transferring EU Rules on State Aid and Public Procurement beyond Europe. Journal of Industry. Competition and Trade 13, 171-186.

Börzel TA, Risse T (2012) From Europeanization to Diffusion: Introduction. West European Politics 35, 1-19.

Bovis CH (2007) European Union Public Procurement Law. Edward Elgar, Cheltenham, UK.

Bovis CH (2013) Public-Private Partnerships in the European Union. Routledge, New York.

Bretherton C, Vogler J (2006) The European Union as a Global Actor, 2nd edn. Routledge, London.

Bretherton C, Vogler J (2013) A Global Actor Past Its Peak? International Relations 27, 375-390.

Casavola HC (2011) The WTO and the EU: Exploring the Relationship between Public Procurement Regulatory Systems. In: Chiti E, Mattarella BG (eds) Global Administrative Law and EU Administrative Law: Relationships, Legal Issues and Comparisons, pp. 293-320. Springer, Berlin.

Conceição-Heldt E (2014) Adaptation and Change in EU Trade Governance: The EU's Paradigm Shift from Multilateralism to Regionalism and Bilateralism. In: Moschella M, Weaver C (eds) Handbook of Global Economic Governance: Players, Power and Paradigms, pp. 57-69. Routledge, London.

Conceição-Heldt E, Meunier S (2014) Speaking with a Single Voice: Internal Cohesiveness and External Effectiveness of the EU in Global Governance. Journal of European Public Policy 21, 961-979.

Crespy A (2014) A Dialogue of the Deaf? Conflicting Discourses over the EU and Services Liberalisation in the WTO. The British Journal of Politics and International Relations 16, 168-187.

Damro C (2007) EU Delegation and Agency in International Trade Negotiations: A Cautionary Comparison. Journal of Common Market Studies 45, 883-903.

Damro C (2015) Market Power Europe: Exploring a Dynamic Conceptual Framework. Journal of European Public Policy 22, $1336-1354$. 
De Bièvre D (2006) The EU Regulatory Trade Agenda and the Quest for WTO Enforcement. Journal of European Public Policy 13, 851-866.

Deutsch KG (2001) The EU: Contending for Leadership. In: Deutsch KG, Speyer B (eds) The World Trade Organization Millennium Round: Freer Trade in the Twenty-First Century, pp. 34-47. Routledge, London.

Duchêne F (1972) Europe's Role in World Peace. In: Mayne R (ed) Europe Tomorrow, pp. 32-47. Fontana, London.

EBRD (European Bank for Reconstruction and Development) (2016) Public Procurement International Standards. [Last accessed 20 Oct 2016.] Available from URL: http://www.ebrd.com/what-we-do/sectors/legal-reform/public-procurement/internationalstandards.html

Elsig M (2002) The EU's Common Commercial Policy: Institutions, Interests and Ideas. Ashgate Pub Ltd, Aldershot.

Elsig M (2007) The EU's Choice of Regulatory Venues for Trade Negotiations: A Tale of Agency Power? Journal of Common Market Studies 45, 927-948.

EC (European Commission) (1996) Public Procurement in the European Union: Exploring the Way Forward. Green Paper (96) 583. EC, Brussels.

EC (2005) Global Europe: Competing in the World. DG External Trade, EC, Brussels.

EC (2007) Main Points from the GPP Expert Meeting 27 November, Stockholm. [Last accessed 06 June 2017.] Available from URL: http://ec.europa.eu/environment/gpp/pdf/28_04_2015/minutes.pdf

EC (2009) National Experts Meeting on Green Public Procurement Reykjavik, 25 ${ }^{\text {th }}$ March. ENV.G2/JM/Ez D (2009). EC, Brussels.

EC (2011) Commission Decision of 3 September 2011 Setting Up a Commission Stakeholder Expert Group on Public Procurement and Replacing Decision 87/305/EEC Setting Up an Advisory Committee on the Opening-up of Public Procurement. 2011/C 291/ 02. EC, Brussels.

EC (2014a) Public Procurement Review Fact Sheet No.1, General Overview. [Last accessed 07 June 2017.] Available from URL: http://www.europarl.europa.eu/ftu/pdf/en/FTU_3.2.2.pdf

EC (2014b) Informal Green Public Procurement Advisory Group (Registry E00453). [Last accessed 07 June 2017.] Available from URL: http://ec.europa.eu/environment/gpp/index_en.htm

EC (2014c) GPP Criteria: Background and Approach. [Last accessed 21 Apr 2016.] Available from URL: http://ec.europa.eu/ environment/gpp/gpp_criteria_en.htm

EC (2015) Trade for All: Towards a More Responsible Trade and Investment Policy. OPOCE, Luxembourg.

EC (2016) Public Procurement. [Last accessed 4 Apr 16.] Available from URL: http://ec.europa.eu/growth/single-market/publicprocurement/index_en.htm

Galtung J (1973) The European Community: A Superpower in the Making. Norwegian Universities Press, Oslo.

Hilf M (1995) The ECJ's Opinion 1/94 on the WTO: No Surprise, but Wise? European Journal of International Law 6, $245-259$.

Hyde-Price A (2006) "Normative” Power Europe: A Realist Critique. Journal of European Public Policy 13, $217-234$.

Jørgensen KE, Oberthür S, Shahin J (2011) Introduction: Assessing the EU's Performance in International Institutions. Journal of European Integration 33, 599-620.

Kohler-Koch B, Finke B (2007) The Institutional Shaping of EU-Society Relations: A Contribution to Democracy via Participation? Journal of Civil Society 3, 205-221.

Levi-Faur D (2005) The Global Diffusion of Regulatory Capitalism. The Annals of the American Academy of Political and Social Science 598 (1), 12-32.

Lucarelli S, Fioramonti L (eds) (2010) External Perceptions of the European Union as a Global Actor. Routledge, London.

Manners I (2002) Normative Power Europe: A Contradiction in Terms? Journal of Common Market Studies 40, $235-258$.

Maughan A (2016) Non-EU Bids on Public Contracts. Lexology, Morrison \& Foerster LLP, Government Contracts Insights. [Last accessed 25 October 2016.] Available from URL: http://www.lexology.com/library/detail.aspx?g=089996eb-85b5-4f79-973clec3ea6ef30e

Maur JC (2005) Exporting Europe's Trade Policy. The World Economy 28, 1565-1590.

Meunier S, Nicolaidis K (2006) The European Union as a Conflicted Trade Power. Journal of European Public Policy 13, 906-925.

Moravcsik A (2002) Reassessing Legitimacy in the European Union. Journal of Common Market Studies 40, 603-624.

OECD (Organisation for Economic Co-operation and Development) (2000) A Comparison of the EC Procurement Directives and the UNCITRAL Model Law, SIGMA Papers No. 28. OECD, Paris.

OECD (2014) 2014 EU Directives: Public Sector and Utilities Procurement, SIGMA Public Procurement Brief 30. OECD, Paris.

Reich A (2009) The New Text of the Agreement on Government Procurement: An Analysis and Assessment. Journal of International Economic Law 12, 989-1022.

Reid TR (2004) The United States of Europe: The New Superpower and the End of American Supremacy. Penguin, New York.

Schimmelfennig F (2010) Europeanization beyond the Member States. Journal for Comparative Government and European Policy 8 , 319-339. 
Semple A (2012) Reform of the EU Procurement Directives and WTO GPA: Forward Steps for Sustainability. In: Albano GL et al. (eds) Charting a Course in Public Procurement Innovation and Knowledge Sharing, pp. 85-118. Academic Press, Boca Raton, FL.

Shaffer G (2006) What's new in EU Trade Dispute Settlement? Judicialization, Public-Private Networks and the WTO Legal Order. Journal of European Public Policy 13, 832-850.

Shaffer G (2015) How the World Trade Organization Shapes Regulatory Governance. Regulation \& Governance 9, 1-15.

Stone D, Ladi S (2015) Global Public Policy and Transnational Administration. Public Administration 93, 839-855.

Trepte P (2005) The Agreement on Government Procurement. In: Macrory PFG, Appleton AE, Plummer MG (eds) The World Trade Organization: Legal, Economic and Political Analysis Volume I, pp. 1123-1163. New York, Springer.

Woolcock S (2012) Public Procurement in International Trade. EP/EXPO/B/INTA/FWC/2009-01/Lot7/28. European Parliament, Directorate General for External Policies, Policy Department, Brussels.

WTO (World Trade Organization) (2012) Annex E: Decision of the Committee on Government Procurement on a Work Programme on Sustainable Development. [Last accessed 22 Dec 2016.] Available from URL: https://www.wto.org/english/ tratop_e/gproc_e/annexe_e.pdf

WTO (2016) Government Procurement and Doha Development Agenda. [Last accessed 20 Apr 2016.] Available from URL: https:// www.wto.org/english/tratop_e/gproc_e/gp_dda_e.htm

Young AR (2015) The European Union as a Global Regulator? Context and Comparison. Journal of European Public Policy 22, 1233-1252.

Young AR, Peterson J (2006) The EU and the New Trade Politics. Journal of European Public Policy 13, $795-814$.

Young AR, Peterson J (2014) Parochial Global Europe: 21st Century Trade Politics. OUP, Oxford.

Zimmermann H (2007) Realist Power Europe? The EU in the Negotiations about China's and Russia's WTO Accession. Journal of Common Market Studies 45, 813-832.

\section{Cases Cited}

Concordia Buses Case, Case C-513/99,[2002] Concordia Bus Finland Oy Ab, formerly Stagecoach Finland Oy Ab v Helsingin kaupunki and HKL-Bussiliikenne ECR I-7213.

EVN Wiestrom Case C-448/01 [2003] EVN AG and Wienstrom GmbH v. Republic of Austria ECR I-14527.

\section{Laws Cited}

Commission Directive 66/683/EEC of 7 November 1966 eliminating all differences between the treatment of national products and that of products which, under Articles 9 and 10 of the Treaty, must be admitted for free movement, as regards laws, regulations or administrative provisions prohibiting the use of the said products and prescribing the use of national products or making such use subject to profitability, OJ 220, 30.11.1966, p. 3748-3750.

Commission Directive 70/32/EEC of 17 December 1969 on provision of goods to the State, to local authorities and other official bodies, OJ L 13, 19.1.1970, p. 1-3.

Council Directive 77/62/EEC of 21 December 1976 coordinating procedures for the award of public supply contracts, OJ: JOL_1977_013_R_0001_004.

Council Directive 89/440/EEC of 18 July 1989 amending Directive 71/305/EEC concerning coordination of procedures for the award of public works contracts, OJ L 210, 21.7.1989, p. 1-21.

Council Directive 89/665/EEC of 21 December 1989 on the coordination of the laws, regulations and administrative provisions relating to the application of review procedures to the award of public supply and public works contracts, OJ L 395, 30.12.1989, p. 33-35.

Council Directive 93/37/EEC of 14 June 1993 concerning the coordination of procedures for the award of public works contracts, OJ L 199, 9.8.1993, p. 54-83.

Directive 2004/17/EC of the European Parliament and of the Council of 31 March 2004 coordinating the procurement procedures of entities operating in the water, energy, transport and postal services sectors, OJ L 134, 30.4.2004, p. 1-113.

Directive 2004/18/EC of the European Parliament and of the Council of 31 March 2004 on the coordination of procedures for the award of public works contracts, public supply contracts and public service contracts, OJ L 134, 30.4.2004, p. 114-240.

Directive 2009/81/EC of the European Parliament and of the Council of 13 July 2009 on the coordination of procedures for the award of certain works contracts, supply contracts and service contracts by contracting authorities or entities in the fields of defence and security, and amending Directives 2004/17/EC and 2004/18/EC (Text with EEA relevance), OJ L 216, 20.8.2009, p. 76-136. 
Directive 2014/23/EU of the European Parliament and of the Council of 26 February 2014 on the award of concession contracts Text with EEA relevance, OJ L 94, 28.3.2014, p. 1-64.

Directive 2014/24/EU of the European Parliament and of the Council of 26 February 2014 on public procurement and repealing Directive 2004/18/EC Text with EEA relevance, OJ L 94, 28.3.2014, p. 65-242.

Directive 2014/25/EU of the European Parliament and of the Council of 26 February 2014 on procurement by entities operating in the water, energy, transport and postal services sectors and repealing Directive 2004/17/EC Text with EEA relevance, OJ L 94, 28.3.2014, p. 243-374.

Agreement on Government Procurement, World Trade Organisation, 1996

Revised Agreement on Government Procurement, World Trade Organisation, 2014.

UNCITRAL Model Law on Procurement of Goods, Construction and Services with Guide to Enactment, United Nations Commission of International Trade Law (UNCITRAL), 1994.

UNCITRAL Model Law on Public Procurement, United Nations, New York, 2014.

Treaty Establishing the European Economic Community, Rome, 25 March 1957.

Single Market Act: improving our work, business and exchanges with one another, 2011.

\section{Appendix}

\section{A.1. List of interviews}

1 Attachée Parlamentaire, Commission du marché intérieur et de la protection des consommateurs, Bureau Parlementaire de Marc Tarabella, April 9, 2014, Brussels.

2 Member of the European Parliament (MEP), Group of the Greens/European Free Alliance, April 10, 2014, Brussels.

3 Deputy Head of Cabinet, Cabinet of European Commissioner for Trade, Karel De Gucht, April 11, 2014, Brussels.

4 Head of Unit, International Dimension of Public Procurement, DG Internal Market and with Services and Legal Officer, International Dimension of Public Procurement, DG Internal Market and Services, April 25, 2014, Brussels.

5 Cabinet Member, Cabinet of the Commissioner Michel Barnier, Internal Market and Services and with Legal Officer, Public Procurement Legislation II, DG Internal Market and Services, May 16, 2014, Brussels.

6 Senior Adviser, Public Procurement, OECD SIGMA, May 2014, Ankara.

7 Head of Office and Parliamentary Adviser to Malcolm Harbour, Chairman of the Internal Market and Consumer Protection Committee, European Parliament, April 17, 2014, Brussels.

8 Senior Adviser, Internal Market Department, Business Europe and Adviser, International Relations Department, Business Europe, May 8, 2014, Brussels.

9 Legal Adviser, ETUC, Confederation of European Trade Unions, June 20, 2014, Brussels.

10 Director General, FIEC, European Construction Industry Federation and Director Economic \& with Legal Affairs, FIEC, European Construction Industry Federation, July 9, 2014, Brussels.

11 Vice President Legal, Anonymous Industry and with Government Affairs Policy Advisor, Anonymous Industry, Representation Office EU, July 14, 2014, Brussels.

12 Head, WTO Secretariat, WTO Committee on Government Procurement, May 25, 2014, Istanbul.

13 Intellectual Property Division WTO, Legal Affairs Officer, WTO Secretariat, May 25, 2014, Istanbul. 